\title{
Purification and Some Properties of Nucleases from Shii-take, Lentinus edodes
}

\author{
Kinji Endo, Yōko UmeYama, Junko NaKaJima and Hiroyasu KaWAI \\ Department of Food Science and Nutrition, Nara Women's University, Nara, 630, Japan
}

Received December 21, 1979

\begin{abstract}
Three kinds of nuclease preparations, each of which having both endonuclease activity that formed 5'-mononucleotides and 3 '-nucleotidase activity, were separated and partially purified from Shii-take, Lentinus edodes. Both enzyme activities of each preparation showed a similar thermostability and electrophoretic mobility on polyacrylamide gel, and a competitive relationship was observed between RNA and 3'-AMP in their enzyme reactions. From these results, it is concluded that both enzyme activities of these three preparations reside in a single protein, respectively. They resemble one another in substrate specificity, cleavage pattern of RNA and thermostability, but are distinguishable from one another by molecular weight, electrophoretic mobility and optimum $\mathrm{pH}$ for degradation of RNA.
\end{abstract}

An accumulation of $5^{\prime}$-nucleotides during the processing of edible mushroom was observed by Mouri et al.,1) and they ${ }^{2)}$ reported the participation of some ribonucleases in this phenomenon. One of $u^{3} s^{3}$ also reported that the water extract of dried Shii-take, fruit body of Lentinus edodes, showed endonuclease activity forming 5'-nucleotides from RNA. It would be useful in the improvement of the processing method of Shii-take to throw light on the properties of the nucleases, as the $5^{\prime}$ GMP formed during the processing is an important tasty substance. The present report describes the purification and some properties of Shii-take nucleases.

\section{MATERIALS AND METHODS}

Materials. Shii-take was purchased in April from Tawara Farm Bureau, Nara prefecture, then dried by the current of heated air at the temperature not exceeding $45^{\circ} \mathrm{C}$, and stored at $5^{\circ} \mathrm{C}$ for use.

Reagents. Yeast RNA and nucleotides were purchased from Kohjin Co., calf thymus DNA (type 1) and degraded DNA (from herring sperm, type IV) from Sigma Chemical Co., DEAE-cellulose, Sephadex G-100 and -200 from Pharmacia Fine Chemicals, and the other reagents from Nakarai Chemicals. Heatdenatured DNA was prepared by heating $10 \mathrm{mg}$ calf thymus DNA in $1 \mathrm{ml}$ of $0.1 \mathrm{M} \mathrm{NaCl}$ solution at $100^{\circ} \mathrm{C}$ for $10 \mathrm{~min}$. According to the method of Heppel and Hilmoe, 5' 5ucleotidase was prepared from bull seminal plasma.

Assay of nuclease activity. The reaction mixture containing $1 \mathrm{ml}$ of $1 \% \mathrm{RNA}$ or DNA, $1 \mathrm{ml}$ of $1 / 7 \mathrm{M}$ veronal acetate buffer and $1 \mathrm{ml}$ of the enzyme solution was incubated at $30^{\circ} \mathrm{C}$ for $30 \mathrm{~min}$. The reaction was stopped by addition of $2 \mathrm{ml}$ of $0.25 \%$ uranyl acetate in $2.5 \%$ perchloric acid solution, and allowed to stand for $15 \mathrm{~min}$ in ice. This followed by centrifugation at $5,000 \mathrm{rpm}$ for $10 \mathrm{~min}$. The supernatant fluid was diluted 5-fold with water and $A_{280}$ was determined against a blank incubated without enzyme. One unit of nuclease activity was defined as the amount which effected an increase in $A_{280}$ of 1.0 per minute.

Assay of nucleotidase activity. The reaction mixture containing $1 \mathrm{ml}$ of $0.5 \% 3^{\prime}$ - or 5 -nucleotide solution, $2 \mathrm{ml}$ of $1 / 7 \mathrm{M}$ veronal acetate buffer and $1 \mathrm{ml}$ of the enzyme solution was incubated at $30^{\circ} \mathrm{C}$ for $30 \mathrm{~min}$. The reaction was stopped by addition of $2 \mathrm{ml}$ of $3 \mathrm{~N}$ perchloric acid. Inorganic orthophosphate liberated was determined colorimetrically at $740 \mathrm{~nm}$ according to the Allen's method. ${ }^{5)}$ One unit of nucleotidase activity was defined as the amount which liberated $1.0 \mu \mathrm{mol}$ orthophosphate per minute.

Protein determination. The protein concentration was determined spectrophotometrically at $280 \mathrm{~nm}$ or at $610 \mathrm{~nm}$ according to the Lowry-Folin's method. ${ }^{6)}$

\section{RESULTS}

Separation and purification of mucleases

Extraction and ammonium sulfate fractionation. The Shii-take dried was ground in a 
mechanical grinder, and then used for enzyme extraction. All operations were carried out at $5^{\circ} \mathrm{C}$ unless otherwise noted. The Shii-take powder was immersed in ten times volume of water, and the mixture was stirred for several hours and centrifuged. The supernatant fluid was brought to $30 \%$ saturation with ammonium sulfate, and kept overnight. After centrifugation of the suspension, the supernatant fluid obtained was brought to $70 \%$ saturation with ammonium sulfate. The precipitate separated by centrifugation was taken up in water and dialyzed against $0.01 \mathrm{M}$ Tris- $\mathrm{HCl}$ buffer of $\mathrm{pH} 7.0$.

Gel filtration. An aliquot of the ammonium sulfate fraction was placed on a Sephadex G-200 column $(7 \times 45 \mathrm{~cm})$ buffered with $0.01 \mathrm{M}$ Tris- $\mathrm{HCl}$ buffer, $\mathrm{pH} 7.0$. Elution was performed with the same buffer, and the fractions of $20 \mathrm{ml}$ were collected at a flow rate of $80 \mathrm{ml}$ /

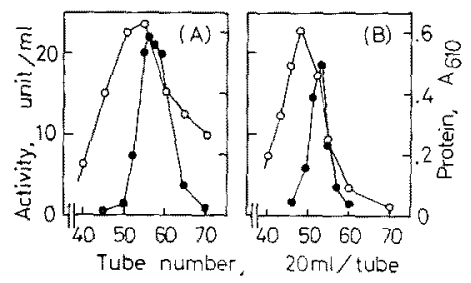

Fig. 1. Gel Filtration of Shii-take Nuclease on Sephadex G-200 (A) and G-100 (B).

(A): The crude enzyme solution prepared by $30 \sim 70 \%$ saturation of ammonium sulfate, $3.6 \mathrm{~g}$ protein, was loaded. (B): The concentrated enzyme solution from tube No. 50 65 in (A), $0.75 \mathrm{~g}$ protein, was loaded. $0-0$, protein, $A_{\theta 10}$ by Lowry-Folin's method; nuclease activity toward RNA.

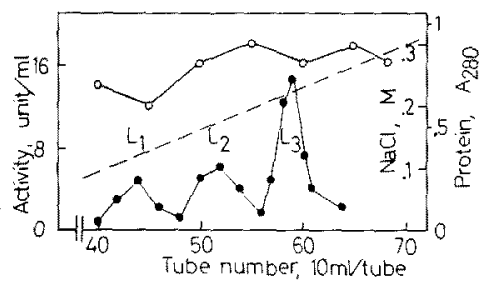

FIG. 2. Chromatography of Shii-take Nuclease on DEAE-cellulose.

The concentrated enzyme solution from tube No. 51 55 in Fig. 1 (B), $0.44 \mathrm{~g}$ protein, was loaded.

-..--, concentration of $\mathrm{NaCl} ; 0-\mathrm{O}$, protein, $A_{280}$; - nuclease activity toward RNA.

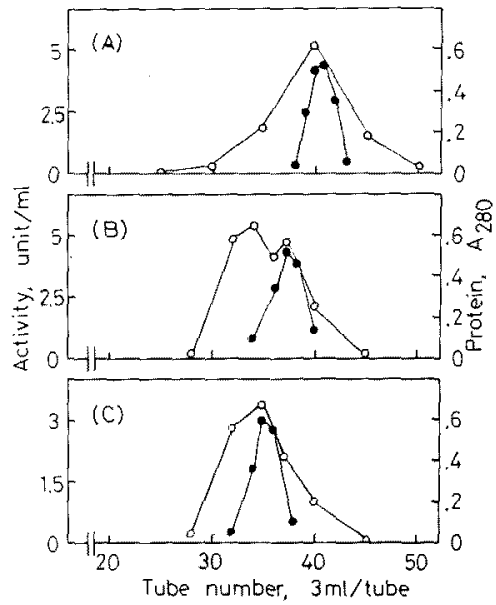

FIG. 3. Final Gel Filtration of Shii-take Nuclease on Sephadex G-100.

(A), (B) and (C) are, respectively, elution patterns of nuclease- $L_{1},-L_{2}$ and $-L_{3}$, shown in Fig. 2. Symbols were the same as described in Fig. 2.

hr. An elution pattern of protein and nuclease activity is shown in Fig. 1A. Nuclease fractions, No. 50 to 65 , were pooled and concentrated by pervaporation. Then the concentrated solution was placed on a column of Sephadex G-100 $(7 \times 52 \mathrm{~cm})$, and gel-filtered with the same buffer. An elution pattern is shown in Fig. 1B. Nuclease fractions, No. 51 to 55 , were pooled, concentrated, and dialyzed against $0.01 \mathrm{M}$ Tris- $\mathrm{HCl}$ buffer, $\mathrm{pH} 7.0$.

DEAE-cellulose chromatography and gel filtration. The nuclease fraction, obtained by the two steps of gel filtration mentioned above, was placed on a DEAE-cellulose column (2.6x $32 \mathrm{~cm}$ ) buffered with $0.05 \mathrm{M}$ Tris- $\mathrm{HCl}$ buffer, pH 7.0. The column was eluted with $250 \mathrm{ml}$ of the same buffer, and then with 1 liter of a linear gradient of 0 to $0.5 \mathrm{M} \mathrm{NaCl}$ in the same buffer. An elution pattern of protein and nuclease activity is shown in Fig. 2, where three peaks with nuclease activity were observed. These peaks were designated in the order of elution as nuclease- $\mathrm{L}_{1},-\mathrm{L}_{2}$ and $-\mathrm{L}_{3}$. These nuclease fractions were gel-filtrated respectively on a Sephadex G-100 column (2.6X $36 \mathrm{~cm}$ ), as shown in Fig. 3. Nuclease- $\mathrm{L}_{1}$ fractions (No. 39 to 42 in Fig. $3 \mathrm{~A}$ ), nuclease- $\mathrm{L}_{2}$ 
Table I. Summary of Purification of Nucleases from Shil-Take

\begin{tabular}{|c|c|c|c|c|c|c|c|c|c|}
\hline \multirow{2}{*}{\multicolumn{2}{|c|}{ Step }} & \multirow{2}{*}{$\begin{array}{l}\text { Protein } \\
\text { (mg) }\end{array}$} & \multicolumn{3}{|c|}{ Activity (unit) } & \multicolumn{3}{|c|}{ Specific activity (unit/mg) } & \multirow{2}{*}{ Ratio $^{6}$} \\
\hline & & & Nuclease $^{b}$ & $3^{\prime}-$ Ntase $^{c}$ & $5^{\prime}-\mathrm{Ntase}^{d}$ & $\begin{array}{l}\text { Nucle- } \\
\text { ase }^{b}\end{array}$ & $\begin{array}{c}3^{\prime}- \\
\text { Ntase }^{c}\end{array}$ & $\begin{array}{c}5^{\prime}- \\
\text { Ntase }^{d}\end{array}$ & \\
\hline \multicolumn{2}{|l|}{ Shii-take extract ${ }^{a}$} & 80,000 & 5,460 & 16,600 & 14,600 & 0.068 & 0.21 & 0.18 & 0.33 \\
\hline \multicolumn{2}{|c|}{ Ammonium sulfate fraction } & 18,500 & 2,530 & 14,600 & 10,500 & 0.14 & 0.79 & 0.57 & 0.17 \\
\hline \multicolumn{2}{|l|}{ Sephadex G-200 } & 6,200 & 1,710 & 8,640 & 930 & 0.28 & 1.4 & 0.15 & 0.20 \\
\hline \multicolumn{2}{|l|}{ Sephadex G-100 } & 960 & 788 & 5,170 & 47 & 0.82 & 5.4 & 0.05 & 0.15 \\
\hline \multirow{3}{*}{ DEAE-cellulose } & $\mathrm{L}_{1}$ & 69 & 96 & 660 & & 1.4 & 9.6 & & \multirow{3}{*}{0.17} \\
\hline & $\mathrm{L}_{2}$ & 65 & 143 & 1,110 & & 2.2 & 17.1 & & \\
\hline & $\mathrm{L}_{3}$ & 72 & 280 & 1,310 & & 3.9 & 18.2 & & \\
\hline \multirow{3}{*}{ Sephadex G-100 } & $L_{1}$ & 30 & 63 & 400 & 0 & 2.1 & 13.3 & 0 & \multirow{3}{*}{0.15} \\
\hline & $L_{2}$ & 35 & 93 & 590 & 0 & 2.7 & 16.9 & 0 & \\
\hline & $L_{3}$ & 61 & 96 & 710 & 0 & 1.6 & 11.6 & 0 & \\
\hline
\end{tabular}

${ }^{a}$ Extract from $1 \mathrm{~kg}$ of Shii-take dried. ${ }^{b}$ Activity toward RNA at pH 5.0. ${ }^{c}$ Activity toward 3'-GMP at $\mathrm{pH}$ 8.0. ${ }^{d}$ Activity toward $5^{\prime}$-AMP at $\mathrm{pH} 6.5 .^{\circledR}$ Total nuclease activity/total $3^{\prime}$-Ntase activity.

fractions (No. 36 to 39 in Fig. 3B) and nuclease$\mathrm{L}_{3}$ fractions (No. 34 to 37 in Fig. 3C) were respectively pooled, and used in the following examinations.

A summary of the separation and the purification of nucleases is shown in Table I, together with 5'-nucleotidase and 3'-nucleotidase activities of nuclease fractions at several steps. From the result, it is obvious that the ratios of nuclease activity to $3^{\prime}$-nucleotidase activity remained nearly constant throughout the purification procedures except the ammonium sulfate fractionation step, where the recovery of nuclease activity was significantly lower than that of $3^{\prime}$-nucleotidase activity. This fact can indicate that the Shii-take extract used contained some nucleases not accompanying with 3 -nucleotidase activity other than the nucleases mentioned below.

\section{Properties of nuclease $-L_{1},-L_{2}$ and $-L_{3}$}

Molecular weight. As mentioned above, nuclease- $\mathrm{L}_{1},-\mathrm{L}_{2}$, and $-\mathrm{L}_{3}$ were respectively eluted as a single peak from a Sephadex G-100 column. From a calibration curve obtained by the gel filtration on the same column with protein markers, as shown in Fig. 4, the molecular weight of nuclease- $\mathrm{L}_{1},-\mathrm{L}_{2}$, and $-\mathrm{L}_{3}$ were estimated to be 28,36 , and $41 \times 10^{3}$, respectively.

Disc gel electrophoresis. Electrophoretic

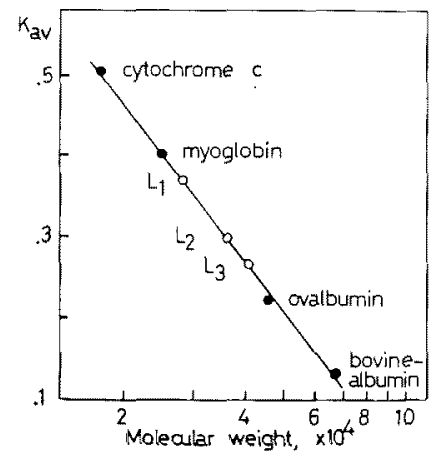

FIG. 4. Determination of Molecular Weight of Nuclease- $\mathrm{L}_{1},-\mathrm{L}_{2}$ and $-\mathrm{L}_{3}$ by Gel Filtration.

The nuclease preparations at the final step and marker proteins were, respectively, loaded on a $2.6 \times 30 \mathrm{~cm}$ column of Sephadex G-100 and eluted with $0.01 \mathrm{~m}$ Tric-HCl buffer, $\mathrm{pH} 7.0$, at a flow rate of $15 \mathrm{ml} / \mathrm{hr}$.

patterns of three nuclease preparations on polyacrylamide gels are shown in Fig. 5. This figure suggests that, although these preparations gave several protein bands, the nuclease activity and the 3 -nucleotidase activity were both associated only with one protein band. The electrophoretic mobilities of these enzyme activities at $\mathrm{pH} 7.5$ increased in the order of nuclease $-\mathrm{L}_{1}<-\mathrm{L}_{2}<-\mathrm{L}_{3}$.

Thermostability. Activities of the nuclease preparations toward RNA and 3'-nucleotide after the heat treatment were determined as shown in Fig. 6 . Both activities of them were stable at temperature below $60^{\circ} \mathrm{C}$ and had the 


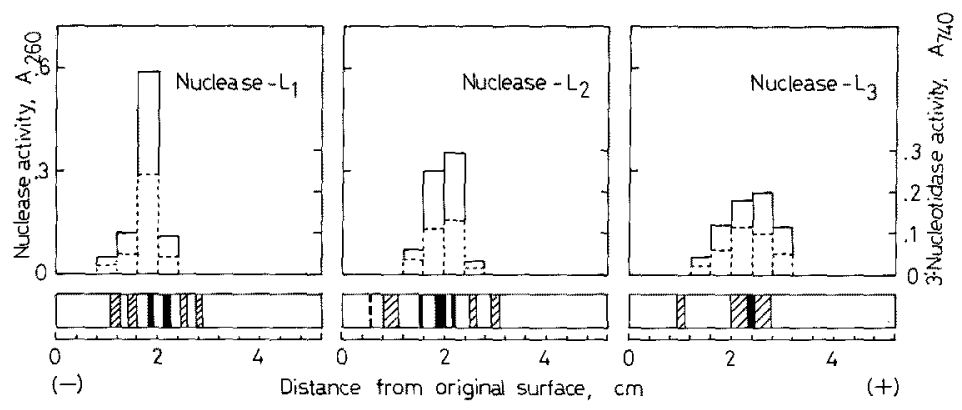

FIG. 5. Distribution of Protein and Enzyme Activity within Polyacrylamide Gel after Electrophoresis of Nuclease- $L_{1},-L_{2}$ and $-L_{3}$.

The nuclease preparations at the final step were, respectively, applied to a $7.5 \%$ polyacrylamide gel, pH 7.5. Electrophoresis was performed at $5^{\circ} \mathrm{C}$ for $80 \mathrm{~min}$ with an applied current at $2 \mathrm{~mA}$ per gel. The gel was cut in half; one half was stained with amido black, the other half was cut into $4 \mathrm{~mm}$ segments. Each segment was extracted with water, and the extracted solutions were assayed for enzyme activities.

Upper figure: - - nuclease activity toward RNA; - . . - - , 3'-nucleotidase activity toward 3'-AMP. Under figure: In these staining patterns of proteins, the depths of stained color were decreased in the order of $\boldsymbol{a}>\lg >$ ?

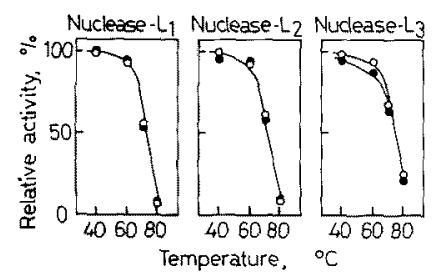

FIg. 6. Thermostability of Nuclease- $\mathrm{L}_{1},-\mathrm{L}_{2}$ and $-\mathrm{L}_{3}$. The nuclease preparations at the final step were heated in $1 / 35 \mathrm{M}$ acetate buffer, $\mathrm{pH} 5.0$, at various temperature for $5 \mathrm{~min}$, and remaining activities were assayed. $0-\mathrm{O}$, nuclease activity toward RNA at $\mathrm{pH} 5.0$; -- $3^{\prime}$-nucleotidase activity toward $3^{\prime}$-AMP at pH 6.5.

same stability on heating.

Effect of $p H$ on the enzyme activities.
Fig. 7, pH-activity curves of three nuclease preparations toward RNA and four kinds of 3 '-nucleotides are shown. The influence of $\mathrm{pH}$ on these enzyme activities varied with the kind of substrates, but there was no significant difference in the variation pattern with kind of substrates among nuclease preparations, except that for RNA the optimum $\mathrm{pH}$ of nuclease- $\mathrm{L}_{1}$ was lower than those of $-\mathrm{L}_{2}$ and $-\mathrm{L}_{3}$. The $\mathrm{pH}$ optima of these preparations for $3^{\prime}$-GMP were higher than those for the other $3^{\prime}$-nucleotides examined, and the activities of them on $3^{\prime}$ nucleotides at their optimal $\mathrm{pH}$ decreased in the order of GMP $>\mathrm{AMP}>\mathrm{CMP} ₹ \mathrm{UMP}$.

Substrate specificity. Data on the subSubstrate specificity.
strate specificity of three nuclease preparations

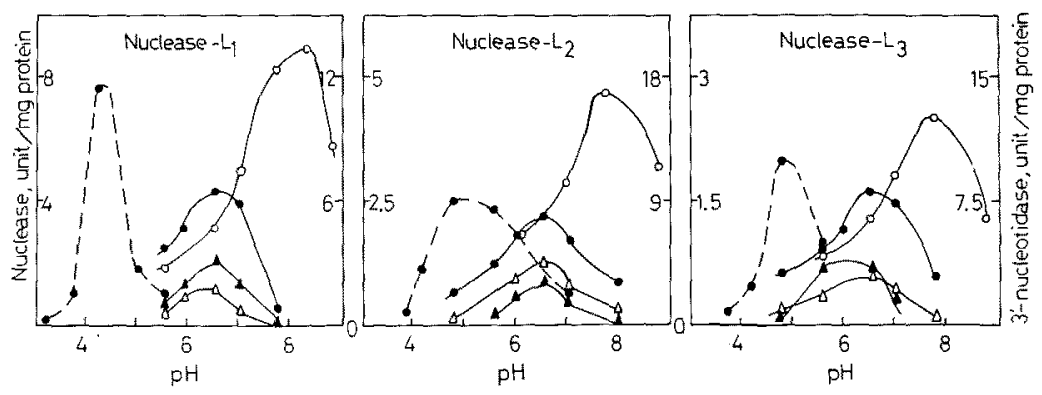

FIG. 7. pH-Activity Curves of Nuclease- $\mathrm{L}_{1},-\mathrm{L}_{2}$ and $-\mathrm{L}_{3}$.

---O, nuclease activity toward RNA; $O-O, 3^{\prime}$-nucleotidase activity toward $3^{\prime}$-GMP; 3'-AMP; $\triangle-\triangle, 3^{\prime}-\mathrm{CMP} ; \Delta-A, 3^{\prime}$-UMP. 
Table II. Substrate Specificity of NUCLEASE- $L_{1},-L_{2}$ AND $-L_{3}$

\begin{tabular}{lrrrr} 
& & & \multicolumn{3}{c}{$(\%)$} \\
\hline \multirow{2}{*}{ Substrate } & pH & \multicolumn{3}{c}{ Nuclease- } \\
\cline { 3 - 5 } & & $\mathrm{L}_{1}$ & $\mathrm{~L}_{2}$ & $\mathrm{~L}_{3}$ \\
\hline Yeast RNA & 5.0 & 100 & 100 & 100 \\
Calf thymus DNA & 5.0 & 0 & 0 & 0 \\
Denatured DNA & 5.0 & 10 & 12 & 10 \\
Degraded DNA & 5.0 & 46 & 52 & 22 \\
Bis-p-NPP ${ }^{a}$ & 5.0 & 0 & 0 & 0 \\
3'-AMP & 6.5 & 100 & 100 & 100 \\
3'-GMP & 6.5 & 76 & 98 & 83 \\
3'-CMP & 6.5 & 49 & 43 & 47 \\
3'-UMP & 6.5 & 27 & 57 & 42 \\
5'-AMP & 6.5 & 0 & 0 & 0 \\
5'-GMP & 6.5 & 0 & 0 & 0 \\
5'-CMP & 6.5 & 0 & 0 & 0 \\
5'-UMP & 6.5 & 0 & 0 & 0 \\
2'-AMP & 6.5 & 0 & 0 & 0 \\
Ribose-5-P & 6.5 & 0 & 0 & 0 \\
Glucose-6-P & 6.5 & 0 & 0 & 0 \\
p-NPP & 6.5 & 0 & 0 & 0 \\
\hline
\end{tabular}

a Bis-p-nitrophenyl phosphate.

b $p$-nitrophenyl phosphate.

are summerized in Table II, where phosphodiesterase activities were determined at $\mathrm{pH} 5.0$ and phosphomonoesterase activities at $\mathrm{pH} 6.5$. It is obvious that the enzyme preparations were free of non-specific phosphodiesterase and nonspecific phosphomonoesterase, and specifically hydrolyzed 3'-nucleotides, RNA, and degraded or denatured DNA.

Cleavage patterns of $R N A$. Time-courses of the formation of products are shown in Fig. 8, during the digestion of RNA by the nuclease preparations. On every cases, the formation of 5 '-nucleotides was slower than that of uranyl reagent-soluble products from

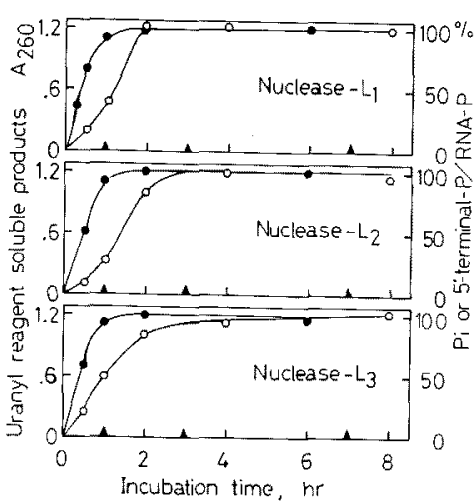

FIG. 8. Formation of Digestion Products of RNA by RNA by Nuclease- $\mathrm{L}_{1},-\mathrm{L}_{2}$ and $\mathrm{L}_{3}$.

The reaction mixture, containing $1 \mathrm{mg}$ RNA and $5 \mu \mathrm{g}$ nuclease protein in $3 \mathrm{ml}$ acetate buffer, $\mathrm{pH} 5.0$, was incubated at $30^{\circ} \mathrm{C}$

- - uranyl reagent-soluble products measured under the standard condition for the nuclease assay; $\mathrm{O}-\mathrm{O}$, released $5^{\prime}$-terminal-P determined as follows: After the nuclease reaction was stopped at $100^{\circ} \mathrm{C}$, the reaction mixture was incubated with 0.2 unit of $5^{\prime}$-nucleotidase at $\mathrm{pH} 7.5,37^{\circ} \mathrm{C}$ for $1 \mathrm{hr}$, and the liberated phosphate was determined.

the RNA, the amount of 5 '-terminal phosphate accumulated at the last stage of the digestion attained to that of total phosphate in the RNA used, and inorganic phosphate was not produced. From these results, it may be concluded that these nuclease preparations cleaved the diester bond in RNA between the phosphate and $3^{\prime}$-hydroxyl group of ribose in a endonucleolytic manner, and they completely hydrolyzed RNA to $5^{\prime}$-mononucleotides.

Competition between substrates. Effects of RNA and 5'-AMP with nuclease preparations were observed on the dephosphorylation of
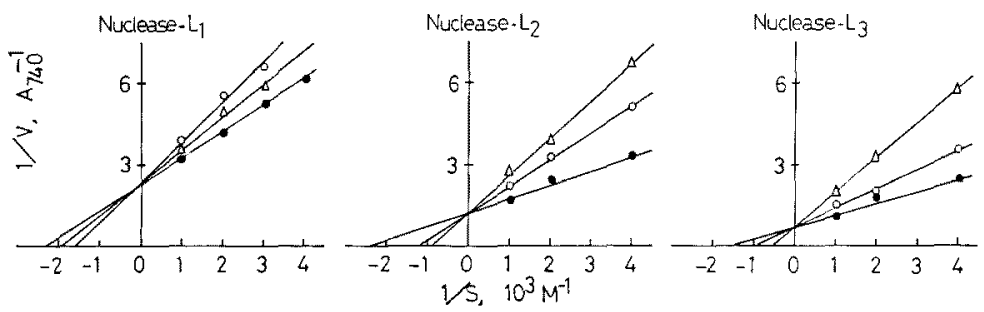

FIG. 9. Competitive Inhibition of $3^{\prime}$-Nucleotidase Activity of Nuclease- $L_{1},-L_{2}$ and $-L_{3}$.

Enzyme activity toward $3^{\prime}$-AMP was assayed at $\mathrm{pH} 5.4$.

Inhibitors added were as follows: - none; $\triangle-\triangle, 1$ mM RNA expressed as phosphate concentration; O-O, $1 \mathrm{~mm} 5^{\prime}$-AMP. 
Table III. Kinetic Parameters of NuCleAse- $\mathrm{L}_{1},-\mathrm{L}_{2}$ AND $-\mathrm{L}_{3}$

\begin{tabular}{|c|c|c|c|}
\hline & \multirow{2}{*}{$\begin{array}{c}K m \text { for } \\
3^{\prime}-\mathrm{AMP} \\
\text { (mM) }\end{array}$} & \multicolumn{2}{|c|}{$K i(\mathrm{~mm})$} \\
\hline & & $\mathrm{RNA}^{a}$ & 5'-AMP \\
\hline Nuclease- $L_{1}$ & 0.41 & 4.1 & 2.0 \\
\hline Nuclease- $\mathrm{L}_{2}$ & 0.39 & 0.56 & 1.1 \\
\hline Nuclease- $\mathrm{L}_{3}$ & 0.64 & 0.59 & 1.4 \\
\hline
\end{tabular}

a Expressed as phosphate concentration.

3'-AMP. Data, shown in Fig. 9, from Lineweaver-Burk's plots clearly indicate that RNA and 5'-AMP inhibited competitively the 3'nucleotidase activities of these nucleases preparations. The kinetic parameters obtained are summerized in Table III. For RNA, the affinity of nuclease- $\mathrm{L}_{1}$ was smaller than those of nuclease $-L_{2}$ and $-L_{3}$, but the affinities of these nucleases for $3^{\prime}$-AMP were resemble one another and were greater than those for 5'-AMP.

\section{DISCUSSION}

In their pioneering study, Mouri et al." separated three ribonuclease fractions from Shii-take by ion-exchange chromatography, and reported that two of them showed the maximum activity between $\mathrm{pH} 4.0$ and 4.5 , and the other one between $\mathrm{pH} 7.0$ and 7.5, and that all of them had the optimum temperature around $60^{\circ} \mathrm{C}$. In the present study, three enzyme preparations, hydrolyzing RNA, were also separated and partially purified from Shiitake. As the $\mathrm{pH}$ optima of the present enzymes for RNA were partially different from those of the previously reported ribonucleases, it is difficult to conclude that the present three enzymes correspond with the previous three ribonucleases. From these studies, however, it may be apparent that Shii-take contains some kinds of thermostable enzymes, which cleave substantially all phosphodiester bonds in RNA to produce exclusively $5^{\prime}$-mononucleotides. The enzymes hydrolyzing RNA in Shii-take would be called nuclease rather than ribonuclease according to the Irie's definition, ${ }^{7}$ because the present results showed that they hydrolyzed denatured DNA as well as
RNA, but did not bis-p-nitrophenylphosphate.

As shown in the present results, it was found that these final nuclease preparations still contained 3'-nucleotidase activity, and that the ratios of nuclease activity to $3^{\prime}$-nucleotidase activity were nearly constant throughout the purification steps. The both enzyme activities of three nuclease preparations showed, respectively, a similar electrophoretic mobility and a similar thermostability. These results suggest that the both enzyme activities of the nuclease preparations reside, respectively, in a single protein. In addition, the competitive relationship observed with the nuclease preparations between RNA and 3'-AMP strongly supports the above suggestion.

Properties of the present nuclease preparations are similar to those of other bifunctional nucleases from higher plants ${ }^{8 \sim 11}$ and fungi ${ }^{12)}$ in the following points: 1) They are 5'-mononucleotide-forming endonuclease, 2) They show 3'-nucleotidase activity, 3) They are more preferential for denatured DNA than native DNA. Of four classes of nucleases classified by Nomura, ${ }^{13)}$ according to the basic structural units recognized by the enzyme as its substrate and to the nature of the phosphomonoester produced by the enzyme action, the Shii-take nucleases partially purified in the present study, as well as the other nucleases cited above, ${ }^{8 \sim 12)}$ may belong to the fourth class which recognizes $3^{\prime}$-phosphate group and attacks 3'-O-P-bond.

Although a similarlity in the substrate specificity was observed among three present nucleases, they could be distinguished from one another by the molecular weight, the electrophoretic mobility and the optimum $\mathrm{pH}$ for RNA. The reason for being several analogous nucleases in Shii-take and their physiological function cannot be well explained at present, but it is clear that the present nucleases would play a key role in the accumulation of tasty nucleotide in Shii-take during the processing. Further purification of Shii-take nucleases and studies on the behaviours of them under the processing are in progress. 


\section{REFERENCES}

1) T. Mouri, W. Hashida, I. Shiga and S. Teramoto, J. Ferment. Technol., 43, 335 (1965).

2) T. Mouri, W. Hashida, I. Shiga and S. Teramoto, J. Ferment. Technol., 44, 248 (1966).

3) Y. Kadowaki, S. Tei, K. Endo and Y. Yamamoto, J. Home Econom. Jpn., 20, 86 (1969).

4) L. A. Heppel and R. J. Hilmoe, J. Biol. Chem., 188, 665 (1951).

5) R. J. L. Allen, Biochem. J., 34, 858 (1940).

6) O. H. Lowry, N. Rosebrough, A. Farr and J. Randall, J. Biol. Chem., 193, 256 (1951).

7) M. Irie, Protein, Nucleic acid, Enzyme, 12, 386
(1967).

8) P. H. Johnson and M. Laskowski Jr., J. Biol. Chem., 243, 3421 (1968).

9) D. M. Hanson and J. L. Fairley, J. Biol. Chem., 244, 2440 (1969).

10) A. Nomura, M. Suno and Y. Mizuno, J. Biochem., 70, 993 (1971).

11) M. Suno, A. Nomura and Y. Mizuno, J. Biochem., 73, 1291 (1973)

12) M. Fujimoto, A. Kuninaka and H. Yoshino, Agric. Biol. Chem., 33, 1517 (1969); 38, 777, 785, 1555 (1974).

13) A. Nomura, Protein, Nucleic acid, Enzyme, 21, 14 (1976). 